\title{
Variovorax sp. Has an Optimum Cell Density to Fully Function as a Plant Growth Promoter
}

\author{
Oyungerel Natsagdorj ${ }^{1,2}{ }^{\text {, Hisayo Sakamoto }}{ }^{2}$, Dennis Marvin O. Santiago ${ }^{3}$, \\ Christine D. Santiago ${ }^{4}$, Yoshitake Orikasa ${ }^{1,2}$, Kazuyuki Okazaki ${ }^{5}$, Seishi Ikeda ${ }^{5}$ and \\ Takuji Ohwada ${ }^{1,2, *}$ \\ 1 United Graduate School of Agricultural Sciences, Iwate University, 18-8 Ueda-sanchome, Morioka, \\ Iwate 020-8550, Japan; oyungereln@ymail.com (O.N.); yosori@obihiro.ac.jp (Y.O.) \\ 2 Department of Life and Food Science, Obihiro University of Agriculture and Veterinary Medicine, Inada-cho, \\ Obihiro, Hokkaido 080-8555, Japan; hisayosakamoto.com@gmail.com \\ 3 Institute of Food Science and Technology, College of Agriculture and Food Science, University of the \\ Philippines Los Baños, Laguna 4031, Philippines; dosantiago1@up.edu.ph \\ 4 Department of Science and Technology Philippines-Philippine Council for Agriculture, Aquatic and Natural \\ Resources Research and Development, Los Baños, Laguna 4030, Philippines; \\ christinesantiago_1017@yahoo.com \\ 5 Hokkaido Agricultural Research Center, National Agriculture and Food Research Organization, 9-4 \\ Shinsei-minami, Memuro-cho, Kasai-gun, Hokkaido 082-0081, Japan; okakazu@affrc.go.jp (K.O.); \\ sikeda67@affrc.go.jp (S.I.) \\ * Correspondence: taku@obihiro.ac.jp; Tel.: +81-155-49-5552
}

Received: 18 February 2019; Accepted: 13 March 2019; Published: 15 March 2019

\begin{abstract}
Utilization of plant growth-promoting bacteria colonizing roots is environmentally friendly technology instead of using chemicals in agriculture, and understanding of the effects of their colonization modes in promoting plant growth is important for sustainable agriculture. We herein screened the six potential plant growth-promoting bacteria isolated from Beta vulgaris L. (Rhizobium sp. HRRK 005, Polaromonas sp. HRRK 103, Variovorax sp. HRRK 170, Mesorhizobium sp. HRRK 190, Streptomyces sp. HRTK 192, and Novosphingobium sp. HRRK 193) using a series of biochemical tests. Among all strains screened, HRRK 170 had the highest potential for plant growth promotion, given its ability to produce plant growth substances and enzymes such as siderophores and 1-aminocyclopropane-1-carboxylic acid (ACC) deaminase, respectively, concomitantly with active growth in a wider range of temperatures $\left(10-30^{\circ} \mathrm{C}\right)$ and $\mathrm{pH}(5.0-10.0)$. HRRK 170 colonized either as spots or widely on the root surface of all vegetable seedlings tested, but significant growth promotion occurred only in two vegetables (Chinese cabbage and green pepper) within a certain cell density range localized in the plant roots. The results indicate that HRRK 170 could function as a plant growth promoter, but has an optimum cell density for efficient use.
\end{abstract}

Keywords: plant growth-promoting bacteria; Variovorax; bioinoculant; GUS staining

\section{Introduction}

Plants associate and form different relationships with diverse microorganisms in nature, including with plant growth-promoting bacteria that efficiently colonize plant roots. While root exudates fuel microbial growth and root tissues provide shelter [1], plant growth-promoting bacteria may accelerate plant growth at different stages via several mechanisms, either simultaneously or sequentially [2]. Today, intensive agriculture depends on excessive use of chemical fertilizers with known public health and environmental hazards [3-5]. Thus, environmentally friendly alternatives such as microorganisms 
have become attractive. Indeed, microbial bioinoculants may potentially reduce the use of chemicals while simultaneously enhancing crop productivity $[5,6]$.

Plant growth-promoting bacteria may interfere with hormone production (e.g., auxin and cytokinin) and promote nutrient uptake (e.g., by solubilizing phosphate or by producing siderophores) $[7,8]$. Some bacteria may promote tolerance against phytopathogens by stimulating systematic resistance, producing hydrolytic enzymes that inhibit interactions with pathogens [3], and alleviating the effect of abiotic stressors by expression of a deaminase that hydrolyzes 1-aminocyclopropane-1-carboxylate (ACC), the immediate ethylene precursor $[7,9]$. Particularly, bacteria that fix nitrogen or solubilize minerals that are not bioavailable have been widely studied under various conditions and soil types for their use as commercial products $[10,11]$, indicating that the mutual association with bacteria is one of the key factors determining plant health, productivity, and soil fertility $[4,5,12]$.

The effectiveness of plant growth-promoting bioinoculants likely depends on bacterial tolerance to abiotic and biotic stress, which is necessary to sustain beneficial interactions with the host plant [8]. Furthermore, the efficiency of bioinoculants is determined by the ability to colonize roots and then to compete with other soil microorganisms and survive. Thus, bacterial adhesion is critical to prevent the loss of plant-microbe interactions [13,14]. Various studies have investigated the mechanisms of efficient plant-microbe interactions. Noirot-Gros et al. [15] reported that the formation of bacterial biofilms, in which microbial cells live in self-synthesized extracellular polymeric substances, resulted in different formations, dispersion, and colonization patterns, followed by plant growth-promoting efficiency. These results suggest that the effect of plant growth-promoting bacteria on plant growth is correlated with the number, dispersion, and colonization of infecting cells associated with their biofilm formations in plant tissues.

Plants are naturally exposed to numerous environmental stresses that affect growth, resulting in massive losses in production [16]. In the Tokachi area, Hokkaido, Japan, volcanic ash causes soil acidity and aluminum toxicity [17], which reduces crop yield by restricting root systems and the uptake of water and nutrients [18]. However, yields of sugar beet, which are important as both a source of sugar and in crop rotation, are persistently high, presumably because of the interactions with useful microorganisms such as plant growth-promoting bacteria [6]. Thus, we anticipated that bacterial strains isolated from the sugar beet may also increase the growth of other plants such as vegetables. Plant growth-promoting bacteria have been reported to mediate the growth promotion of vegetables caused by the increased nutrient availability and phytohormones regulation, resulting in high quality, safety, and freshness [10].

In a previous study, bacterial strains having a high affinity with the sugar beet (Beta vulgaris L. cv. Rycka) were examined for their plant growth-promotive abilities (Kenkyuseika, vol. 539. 2015. Tsukuba Office, Agriculture, Forestry and Fisheries Research Council Secretariat, Japan). In this study, we selected six potential plant growth-promoting bacterial strains (Rhizobium sp. HRRK 005, Polaromonas sp. HRRK 103, Variovorax sp. HRRK 170, Mesorhizobium sp. HRRK 190, Streptomyces sp. HRTK 192, and Novosphingobium sp. HRRK 193), and compared their biochemical characteristics in order to identify the strain with the highest ability of plant growth promotion. Then, the selected strain, Variovorax sp. HRRK170, was evaluated for its ability to promote plant growth using vegetable seedlings. The results demonstrate that HRRK170 is a plant growth promoter with beneficial biochemical properties, but has an optimum cell density for its full function.

\section{Materials and Methods}

\subsection{Bacterial Strains and Growth Conditions}

Bacterial strains with high affinity for sugar beet roots (Beta vulgaris L. cv. Rycka) [19] were previously studied for their plant growth promotion (Kenkyuseika, vol. 539. 2015. Tsukuba Office, Agriculture, Forestry and Fisheries Research Council Secretariat, Japan). Among them, six potential plant growth-promoting bacterial strains, Rhizobium sp. HRRK005 (NITE P-01604), Polaromonas sp. 
HRRK103 (NITE P-01607), Variovorax sp. HRRK170 (NITE P-01608), Mesorhizobium sp. HRRK190 (NITE P-01609), Streptomyces sp. HRTK192 (NITE P-01614), and Novosphingobium sp. HRRK193 (NITE P-01610), were used in this study. All strains were grown in R2A medium (BD, Sparks, MD, USA), and preculture was adjusted based on $\mathrm{OD}\left(\mathrm{OD}_{600}=0.1\right)$ to initiate culture. To determine growth at different temperatures and $\mathrm{pH}$, a portion of preculture, grown aerobically in $\mathrm{R} 2 \mathrm{~A}$ medium at $30{ }^{\circ} \mathrm{C}$, was transferred into the same fresh medium and grown at $10,20,30$, and $40{ }^{\circ} \mathrm{C}$ or into the fresh medium adjusted to $\mathrm{pH} 4.0,5.0,6.0,8.0,9.0$, and 10.0 , and grown at $30^{\circ} \mathrm{C}$. Growth was monitored at $660 \mathrm{~nm}$ by using a biophotorecorder (TVS062CA; Advantec Co., Tokyo, Japan).

\subsection{Biochemical Characteristics}

Production of indole-3-acetic acid (IAA) was quantified by high performance liquid chromatography (HPLC) analysis using ethyl acetate extraction method [11]. In brief, bacterial cells were grown in $200 \mathrm{~mL} \mathrm{R} 2 \mathrm{~A}$ broth containing $2 \mathrm{mM}$ L-tryptophan at $30^{\circ} \mathrm{C}$ and $130 \mathrm{rpm}$ for 7 days. The supernatants were collected by centrifuging at $9800 \times \mathrm{g}$ for $3 \mathrm{~min}$, and after $\mathrm{pH}$ was adjusted to 2.8 by using $1 \mathrm{~N} \mathrm{HCI}$, IAA was extracted with $200 \mathrm{~mL}$ ethyl acetate, twice. Then, the ethyl acetate fraction was evaporated under vacuum and the residue was dissolved using $1 \mathrm{~mL}$ methanol. Samples were filtered through a membrane filter (pore size, $0.2 \mu \mathrm{m}$ ) prior to HPLC analysis (Tosoh Co., Tokyo, Japan). IAA production levels were expressed as micrograms of IAA per mg dry weight of cells.

Siderophore production was evaluated using chrome azurol S shuttle assay [20] with minor modifications. In brief, bacterial precultures $(50 \mu \mathrm{L})$ were inoculated into $5 \mathrm{~mL}$ of R2A broth and incubated at $30^{\circ} \mathrm{C}$ and $130 \mathrm{rpm}$ for 7 days. After centrifugation, $900 \mu \mathrm{L}$ of the supernatant $(n=4)$ was incubated for 20 min with $100 \mu \mathrm{L}$ chrome azurol $\mathrm{S}$ and $10 \mu \mathrm{L}$ of $400 \mathrm{mM}$ sulfosalicylic acid, the shuttle agent. As described above, the R2A broth $(900 \mu \mathrm{L})$ reacted with chrome azurol $\mathrm{S}$ and was used as a reference. Siderophore production levels were expressed as the ratio of the final absorbance value of the sample [absorbance of the reference solution at $\mathrm{OD}_{630}$ minus absorbance of sample at $\mathrm{OD}_{630}$ ] against the reference solution.

Biofilm production was determined by microtiter plate assay [21], in which bacterial precultures adjusted to the same initial $\mathrm{OD}\left(\mathrm{OD}_{600}=0.1\right)$ were incubated statically at $20^{\circ} \mathrm{C}$ for $48 \mathrm{~h}$ in 96 -well polystyrene microplates. After removing the culture, the wells were air-dried and stained for $45 \mathrm{~min}$ with $200 \mu \mathrm{L}$ of $1 \%$ crystal violet (FUJIFILM Wako Pure Chemical Co., Osaka, Japan). After dissolving in $95 \%$ ethanol, the product was assayed at $595 \mathrm{~nm}$ using a microplate reader (iMark, Bio-Rad Laboratories, Irvine, CA, USA).

Enzyme assays were conducted as described previously, but with slight modifications [22]. The 1-aminocyclopropane-1-carboxylic acid (ACC) deaminase activity was determined by measuring the amounts of $\alpha$-ketobutyrate produced by the reaction. Briefly, bacterial cells were grown in R2A medium at $30{ }^{\circ} \mathrm{C}$ and $130 \mathrm{rpm}$ for $48 \mathrm{~h}$, and after centrifugation, washed with $5 \mathrm{~mL}$ of DF salts minimal medium [23]. Then, the cells were resuspended in $7.5 \mathrm{~mL} \mathrm{DF}$ salts minimal medium containing $3 \mathrm{mM}$ ACC and grown for $24 \mathrm{~h}$ to induce ACC deaminase activity. After the cells were washed with $1 \mathrm{~mL}$ of $0.1 \mathrm{M}$ Tris- $\mathrm{HCl}(\mathrm{pH} 7.6)$ and resuspended in $600 \mu \mathrm{L}$ of $0.1 \mathrm{M}$ Tris- $\mathrm{HCl}(\mathrm{pH}$ 8.5), they were mixed with $30 \mu \mathrm{L}$ toluene. Subsequently, the suspension $(200 \mu \mathrm{L})$ was supplemented with $20 \mu \mathrm{L}$ of $0.5 \mathrm{M}$ ACC and $1 \mathrm{~mL}$ of $0.56 \mathrm{M} \mathrm{HCl}$ and further acidified with $800 \mu \mathrm{L}$ of $0.56 \mathrm{M} \mathrm{HCl}$, incubated at $30^{\circ} \mathrm{C}$ for $15 \mathrm{~min}$. Next, $300 \mu \mathrm{L}$ of $0.2 \%$ 2,4-dinitrophenylhydrazine was added to the mixture and incubated at $30^{\circ} \mathrm{C}$ for $30 \mathrm{~min}$. The activity was expressed by the formation of $\alpha$-ketobutyrate (nanomole per $\mathrm{mg}$ of cell for $1 \mathrm{~h}$ at given conditions).

$\beta-1,3$-glucanase activity was evaluated by measuring the amounts of reducing sugar released from laminarin. Briefly, bacterial cultures grown for $48 \mathrm{~h}$ in $1 \%$ colloidal chitin (Sigma-Aldrich, St. Louis, MI, USA) at $30{ }^{\circ} \mathrm{C}$ and $130 \mathrm{rpm}$ were centrifuged at $4{ }^{\circ} \mathrm{C}$ and $9800 \times g$, and $1 \mathrm{~mL}$ of the resulting supernatant was reacted at $40{ }^{\circ} \mathrm{C}$ for $1 \mathrm{~h}$ with $0.1 \mathrm{~mL}$ of $2 \%$ laminarin in $0.2 \mathrm{M}$ acetate buffer (pH 5.4). Development of brown color was quantified at $530 \mathrm{~nm}$. A standard curve was plotted using glucose, 
and one unit of the activity was defined as the amount of enzyme that liberates one micromole of glucose per hour at the indicated conditions.

Bacterial chitinase activity was measured on R2A agar plates supplemented with colloidal chitin [24], while cellulase activity was quantified on LB plates with carboxymethyl cellulose [25]. Lipase activity was assessed on R2A agar plates with Tween 20 (FUJIFILM Wako Pure Chemical Co., Osaka, Japan) as substrate [26]. These enzyme activities were quantified based on the diameter of halo zones formed around colonies after bacterial precultures $(5 \mu \mathrm{L})$ were spotted on plates and incubated at $30{ }^{\circ} \mathrm{C}$ for 7 days.

\subsection{Morphological Observation of HRRK170 by Scanning Electron Microscopy}

HRRK170 colonies grown on R2A agar plates were visualized on a scanning electron microscope according to the conventional method. Briefly, cells grown at $30^{\circ} \mathrm{C}$ for $48 \mathrm{~h}$ on R2A agar were smeared on a glass slide and, after immersion in $2 \%$ glutaraldehyde for $2 \mathrm{~h}$, washed with $0.1 \mathrm{M}$ phosphate buffer for $15 \mathrm{~min}$, three times. Specimens were then treated with $50 \%, 75 \%$, and $99.5 \%$ ethanol for $15 \mathrm{~min}$, in this order, and immersed at $40{ }^{\circ} \mathrm{C}$ for $15 \mathrm{~min}$ three times in $99.0 \%$ tertiary butyl alcohol. Then, samples were lyophilized, coated with gold using an MSP-mini magnetron sputter (VD, Ibaraki, Japan), and imaged on a Miniscope TM3030 (Hitachi Hi-Tech Co., Tokyo, Japan).

\subsection{Effect of HRRK170 on the Plant Growth}

PotAce N potting soil (Katakura \& Co-op Agri, Tokyo, Japan) was used to assess the plant growth. Vegetable seeds [cabbage (Brassica oleracea L. cv. Harunami), lettuce (Lactuca sativa L. cv. Cisco), tomato (Solanum lycopersicum L. cv. Momotaro), radish (Raphanus raphanistrum L. cv. Taibyo sobutori), eggplant (Solanum melongena L. cv. Senryo no.2), Chinese cabbage (Brassica rapa L. cv. Kigokoro 85, Kigokoro 65, Haregi 85, and Okiniiri), and green pepper (Capsicum annuum L. cv. Kyomidori, Kyonami, Ace, and Pitaro)] were purchased from Takii Seeds Co., Ltd. (Kyoto, Japan). Sugar beet seeds (Beta vulgaris L. cv. Rycka) were used as a reference and were provided by the Hokkaido Agricultural Research Center, National Agriculture and Food Research Organization, Hokkaido, Japan.

The vegetable seeds were sterilized with $70 \%$ ethanol for $1 \mathrm{~min}, 1 \%$ sodium hypochlorite for $1 \mathrm{~min}$, and then rinsed with sterilized distilled water (three times). Radish and eggplant seeds were treated ultrasonically (200 W; US-105, SND Co., Ltd., Nagano, Japan) for 1 min (two times) before sterilization. Sugar beet seeds were left under running tap water for $24 \mathrm{~h}$, sterilized with $70 \%$ ethanol for $1 \mathrm{~min}, 0.5 \%$ sodium hypochlorite containing $0.1 \%$ Tween 20 for $15 \mathrm{~min}$, and then rinsed with sterilized distilled water for $15 \mathrm{~min}$ (three times). Sterilized seeds were sown on plug trays containing approximately $100 \mathrm{~g}$ soil and inoculated with $1 \mathrm{~mL}$ of $8.5 \times 10^{7} \mathrm{CFU} \mathrm{mL}{ }^{-1}$ HRRK170 cells per 4 seeds. Seeds were covered with aluminum foil for 7 days, and then grown for three weeks in a growth chamber (BiOTRON; NK system, Osaka, Japan) under cycles of $14 \mathrm{~h}$ light at $23.5^{\circ} \mathrm{C}$ and $10 \mathrm{~h}$ dark at $20.0^{\circ} \mathrm{C}$. Plant parts above ground were weighed before and after drying at $60^{\circ} \mathrm{C}$ for 3 days, to obtain the fresh and dry weights, respectively.

\subsection{Tissue Localization of HRRK170 in Plant Roots}

To observe plant tissue localization of HRRK170, a reporter gene, gusA, was introduced into the cells to construct GUS-labeled cells using methods described previously [27]. Briefly, Escherichia coli S17-1 harboring the plasmid pmTn5SSgusA20 (donor) and HRRK 170 (recipient) cells were mixed, and after centrifugation, cell pellets were resuspended in $50 \mu \mathrm{L}$ of $0.85 \% \mathrm{NaCl}$. Mating was performed at $30{ }^{\circ} \mathrm{C}$ for 2 days on a membrane filter (mixed cellulose ester; pore size $0.45 \mu \mathrm{m}$, Advantec Co., Tokyo, Japan) placed on R2A agar plate containing spectinomycin $\left(100 \mu \mathrm{g} \mathrm{mL} \mathrm{L}^{-1}\right)$, streptomycin $\left(40 \mu \mathrm{g} \mathrm{mL} \mathrm{L}^{-1}\right)$, and tetracycline $\left(15 \mu \mathrm{g} \mathrm{mL}^{-1}\right)$. Transformed HRRK170 cells were confirmed to promote plant growth to a similar extent as the wild type.

Sterilized seeds were sown on $1.5 \%$ agar plates and covered with aluminum foil prior to germination. Seedlings were then transferred to $0.3 \%$ agar plates containing a 2000 -fold dilution 
of HYPONeX 6-10-5 (HYPONeX, Osaka, Japan), and after inoculation with $100 \mu \mathrm{L}$ of GUS-labeled HRRK170 cells $\left(8.5 \times 10^{7} \mathrm{CFU} \mathrm{mL}{ }^{-1}\right)$ per seedling, grown in a growth chamber (BiOTRON; NK system, Osaka, Japan) under the same conditions described above. HRRK170 cells localized in seven-day-old seedlings were stained in a GUS-staining solution containing $16 \mathrm{~mL}$ of $125 \mathrm{mM}$ sodium phosphate buffer (pH 7.0), $80 \mu \mathrm{L}$ of $0.5 \mathrm{M} \mathrm{Na}_{2}$ EDTA ( $\mathrm{pH} 8.0$ ), $200 \mu \mathrm{L}$ of $2 \% 5$-bromo-4-chloro-3-indolyl$\beta$-D-glucuronide cyclohexylammonium salt, $80 \mu \mathrm{L}$ of $10 \%$ sodium dodecyl sulfate, and $23.6 \mathrm{~mL}$ of distilled water. The staining was performed in de-aired conditions for $90 \mathrm{~min}$ and then left at $30^{\circ} \mathrm{C}$ for $2 \mathrm{~h}$ prior to use. Microscopic observation of the localized HRRK170 cells in seedlings was conducted using a stereomicroscope (SZX16, Olympus Co., Tokyo, Japan). In parallel, agar (5\%)-embedded sections of roots were sliced using a microslicer (DTK1000 ZERO1, Dosaka EM Co., Ltd, Kyoto, Japan) and the localization of cells inside the plant tissues was observed under an inverted microscope (BZ-X700, Keyence Co., Osaka, Japan).

\subsection{Calculation of HRRK170 Cell Density Using Color Development by GUS Staining}

To quantify HRRK170 cell density by color development of GUS-staining solution, the correlation between HRRK170 cell density and the absorbance value $\left(\mathrm{OD}_{615}\right)$ of GUS-staining solution was examined. GUS-labeled HRRK170 cells were grown at $30^{\circ} \mathrm{C}$ and $130 \mathrm{rpm}$, overnight in R2A broth containing the antibiotics described above, and serially diluted cell suspensions were prepared. After $2 \mathrm{~mL}$ of each diluted cell suspension was centrifuged at $4{ }^{\circ} \mathrm{C}$ and $18,000 \times g$ for $5 \mathrm{~min}$, the resultant cell pellets were suspended in $2 \mathrm{~mL}$ GUS-staining solution and stained as described above. After removing cells by centrifugation, the absorbance $\left(\mathrm{OD}_{615}\right)$ of the supernatant was measured using a spectrophotometer (Ultrospec 3100 pro, GE Healthcare Life Sciences, Buckinghamshire, UK). In parallel, the cell number involved in each diluted cell suspension was also determined using the plate dilution method to make a correlogram with the $\mathrm{OD}_{615}$ values of GUS-staining solution. To calculate the plant-infected cell density of HRRK170, 10 seedlings inoculated with GUS-labeled HRRK170 cells were mixed with $20 \mathrm{~mL}$ of GUS-staining solution, and the absorbance $\left(\mathrm{OD}_{615}\right)$ of the solution was measured. Then, the cell number was calculated using the correlogram, and cell density was expressed as the infected cell number per $g$ weight of plant.

\subsection{Statistical Analysis}

The statistical analysis was performed using IBM SPSS Statistics for Windows v.23.0 (IBM, Armonk, NY, USA). Data were subjected to the Student's $t$-test. A Tukey's honestly significant difference test with post-hoc comparison at the $5 \%$ confidence level was used to compare mean values among treatments. Experiments were performed with at least three replicates for each treatment.

\section{Results}

\subsection{Bacterial Growth Under Different Temperatures and $p H$ Values}

Figure 1 shows growth profiles of the six strains (Rhizobium sp. HRRK005, Polaromonas sp. HRRK103, Variovorax sp. HRRK170, Mesorhizobium sp. HRRK190, Streptomyces sp. HRTK192 and Novosphingobium sp. HRRK193) under different temperatures and $\mathrm{pH}$ ranges. All bacterial strains grew at 20 and $30{ }^{\circ} \mathrm{C}$. HRRK170 showed the most active growth at both temperatures with a growth peak at $24 \mathrm{~h}$ after incubation. In addition, HRRK170 also showed the highest growth at $10^{\circ} \mathrm{C}$ (Figure 1A). Only HRTK192 grew at $40{ }^{\circ} \mathrm{C}$, but showed a lag time of $24 \mathrm{~h}$ at $20^{\circ} \mathrm{C}$. The growth of HRRK193 was active at $20^{\circ} \mathrm{C}$ and close to that of HRRK170. However, its growth at $30^{\circ} \mathrm{C}$ was considerably slower than that of HRRK170 and HRTK192. The other strains, HRRK005, 103, and 190, showed similar growth profiles and their growth was slower at both 20 and $30^{\circ} \mathrm{C}$, although HRRK103 grew slowly at $10{ }^{\circ} \mathrm{C}$ (Figure 1A). For pH, all strains grew at pH 6.0 to 9.0. Among them, HRRK170 exhibited active growth in a wide range of $\mathrm{pH}$ values (5.0 to 10.0) with a growth peak at approximately $24 \mathrm{~h}$. HRTK192 also exhibited active growth from $\mathrm{pH} 5.0$ to 9.0, which was close to that of HRRK170 at $24 \mathrm{~h}$ after incubation. 
However, growth was inhibited at pH 10.0. HRRK103 showed the highest growth at pH 6.0 and 10.0, but growth at other $\mathrm{pH}$ values was lower than that of HRRK170 at $24 \mathrm{~h}$ after incubation. Growth of HRRK005, 190, and 193 was slower than that of these three strains at pH 6.0 to 8.0, and HRRK005 showed no growth at $\mathrm{pH} 5.0$ and 10.0. These results indicated that HRRK170 had the highest ability to grow in a wider range of temperatures $\left(10\right.$ to $\left.30^{\circ} \mathrm{C}\right)$ and $\mathrm{pH}$ values (5.0 to 10.0) among the six strains.
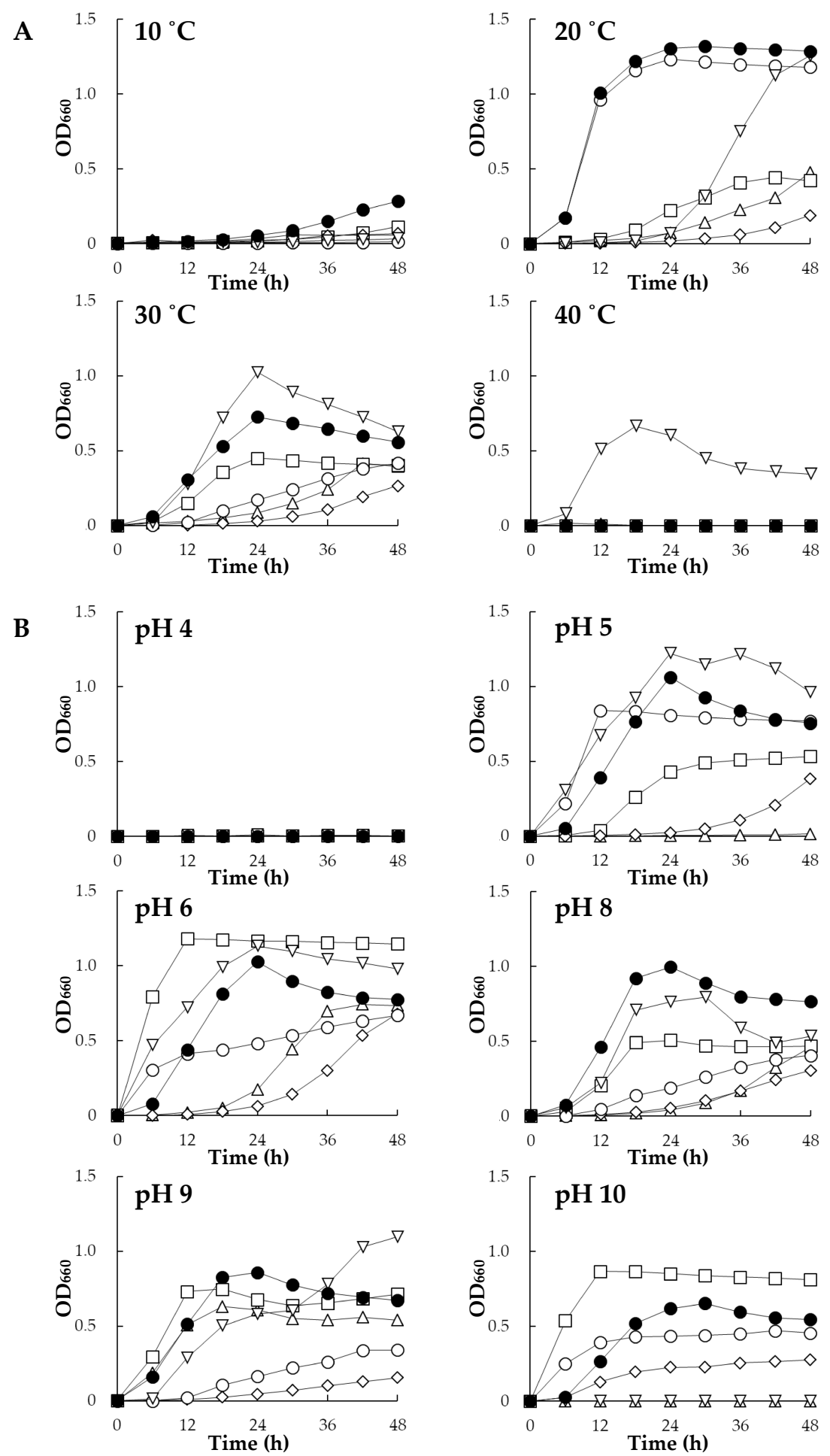

Figure 1. Growth of six plant growth-promoting bacteria under different temperatures (A) and $\mathrm{pH}$ values (B). Growth was monitored at $\mathrm{OD}_{660}$ using a biophotorecorder. Data are the means of three replicates. Symbols: $\triangle$, HRRK005; $\square$, HRRK103; •, HRRK170;, HRRK190; $\nabla$, HRTK192; ○, HRRK193. 


\subsection{Biochemical Characteristics of Six Strains}

Based on the growth profiles of six strains under different temperatures and $\mathrm{pH}$ values as shown in Figure 1, we investigated their biochemical activities in order to evaluate their abilities to produce plant growth substances and enzymes at $30{ }^{\circ} \mathrm{C}\left(20{ }^{\circ} \mathrm{C}\right.$ for biofilm production $)$ and a neutral $\mathrm{pH}$ (Table 1). All six strains produced siderophores, biofilm, and IAA. Particularly, HRRK170 exhibited higher production of these compounds and the production levels of siderophores and biofilm were the highest among the six strains (52.63 and 0.46 , respectively) (Table 1). Regarding enzyme production, activity of ACC deaminase and $\beta-1,3$-glucanase was also observed in almost all of the six strains. However, the level of ACC deaminase produced by HRRK170 was significantly higher than that of the other strains, and the level reached approximately $60.41\left(\mathrm{nmol} \mathrm{AKB} \mathrm{mg} \mathrm{H}^{-1} \mathrm{cell} \mathrm{h}^{-1}\right)(p<0.001)$ (Table 1). Both cellulase and lipase activities were detected in HRRK005, HRRK170, and HRTK192, but chitinase activity was detected only in HRRK005 (Table 1). Results obtained from the biochemical analyses as well as the growth profile indicated that HRRK170 had the highest potential as a plant growth promoter.

Table 1. Biochemical activities of six plant growth-promoting bacteria.

\begin{tabular}{|c|c|c|c|c|c|c|c|c|}
\hline \multirow[b]{2}{*}{ Strain } & \multicolumn{7}{|c|}{ Plant Growth-Promoting Compounds and Enzyme Activities } & \multirow[b]{2}{*}{$\begin{array}{l}\text { Chitinase } \\
\text { (mm dia.) }\end{array}$} \\
\hline & $\begin{array}{c}\text { Siderophore } \\
(\%)\end{array}$ & $\begin{array}{l}\text { Biofilm } \\
\left(\mathrm{OD}_{595}\right)\end{array}$ & $\begin{array}{c}\text { IAA }\left(\mu \mathrm{g} \mathrm{mg}^{-1}\right. \\
\text { Dry cell) }\end{array}$ & $\begin{array}{c}\text { ACC } \\
\text { Deaminase } \\
\text { (nmol AKB } \\
\mathrm{mg}^{-1} \text { Cell } \\
\left.\mathrm{h}^{-1}\right)\end{array}$ & $\begin{array}{c}\beta-1,3- \\
\text { Glucanase } \\
\left(\mathrm{U} \mathrm{mL}^{-1}\right)\end{array}$ & $\begin{array}{l}\text { Cellulase } \\
\text { (mm dia.) }\end{array}$ & $\begin{array}{c}\text { Lipase } \\
\text { (mm dia.) }\end{array}$ & \\
\hline HRRK005 & $17.87 \pm 0.23^{\mathrm{b}}$ & $0.26 \pm 0.01^{\mathrm{a}}$ & $92.55 \pm 0.55^{\mathrm{c}}$ & n.d. & $0.02 \pm 0.03^{\mathrm{a}}$ & $0.35 \pm 0.15^{\mathrm{a}}$ & $1.34 \pm 0.56^{\mathrm{b}}$ & $0.50 \pm 0.08$ \\
\hline HRRK190 & $13.07 \pm 3.02^{\mathrm{a}}$ & $0.25 \pm 0.03^{\mathrm{a}}$ & $92.54 \pm 3.79^{c}$ & $5.86 \pm 0.50^{\mathrm{b}}$ & $0.67 \pm 0.30^{\mathrm{b}}$ & n.d. & n.d. & n.d \\
\hline HRTK192 & $10.77 \pm 1.45^{\mathrm{a}}$ & $0.43 \pm 0.06^{\mathrm{b}}$ & $118.00 \pm 0.82^{\mathrm{e}}$ & $20.74 \pm 1.92^{c}$ & $0.46 \pm 0.11^{\mathrm{b}}$ & $2.24 \pm 0.40^{\mathrm{b}}$ & $3.36 \pm 0.66^{c}$ & n.d \\
\hline HRRK193 & $11.99 \pm 2.32^{\mathrm{a}}$ & $0.44 \pm 0.09^{\mathrm{b}}$ & $16.43 \pm 0.42^{\mathrm{a}}$ & $19.58 \pm 0.00^{c}$ & $1.46 \pm 0.11^{\mathrm{c}}$ & n.d. & n.d. & n.d \\
\hline
\end{tabular}

Values are means \pm standard deviation. The significance of differences between means was compared using one-way analysis of variance. Mean values in the same column with common superscript letters are not significantly different $(p \leq 0.05)$ by Tukey's honestly significant difference test. n.d.: not detected.

\subsection{Morphological Characteristics of HRRK170}

Figure 2 shows morphological characteristics of Variovorax sp. HRRK170 grown on an R2A agar plate. HRRK170 cells grown on R2A agar were gelatinous, glistening, yellowish, and robustly proliferative. However, the colony shape was obscure and smeary (Figure 2A). In addition, cells were straight or slightly curved rods, approximately $1.5 \mu \mathrm{m}$ long, and embedded in a mucilaginous layer due to its ability to produce biofilm, as visualized using scanning electron microscopy (Figure 2B).

\section{A}

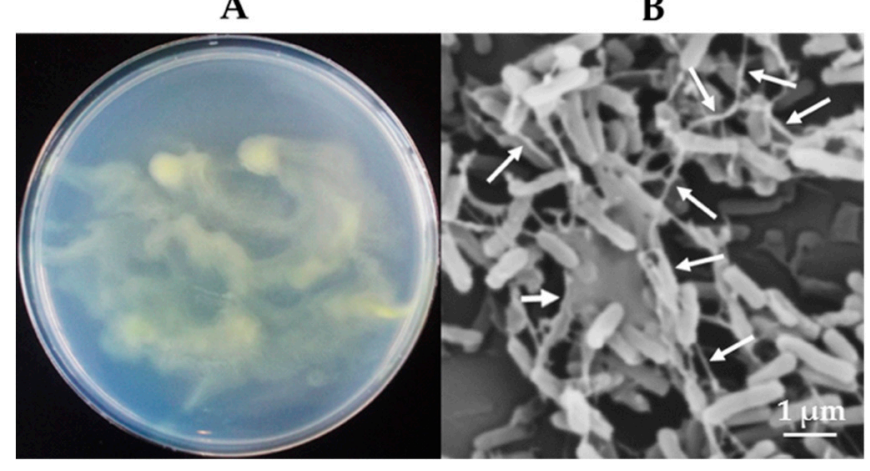

Figure 2. Morphological characteristics of Variovorax sp. HRRK170 cells. (A) Cells grown on R2A agar at $30{ }^{\circ} \mathrm{C}$ for $48 \mathrm{~h}$. (B) Microscopic observation of HRRK 170 cells grown on R2A agar using a scanning electron microscope. Biofilms produced by HRRK 170 are indicated by the arrows. 


\subsection{Effect of HRRK170 on the Growth of Vegetable Seedlings}

Figure 3 shows the inoculation effect of Variovorax sp. HRRK170 on the growth of seven vegetable seedlings in addition to sugar beet, which was used as a reference. The results showed that HRRK170 significantly promoted the growth of Chinese cabbage and green pepper as well as sugar beet compared with the uninoculated control (ratio (\%) of the weights of inoculated plants against those of uninoculated plants: Chinese cabbage, 142.4 and 157.1; green pepper, 149.0 and 200.2; sugar beet, 124.1 and 137.8, in terms of fresh and dry weights, respectively). The growth of eggplant also significantly increased with the inoculation of HRRK170 in terms of dry weights (ratio (\%) against the uninoculated control: 118.9). In contrast, the growth of tomato and lettuce significantly decreased in terms of dry weights, particularly that of tomato, which was significantly decreased with the inoculation in terms of both fresh and dry weights (ratio (\%) against the uninoculated control: 72.5 and 53.0, in fresh and dry weights, respectively).
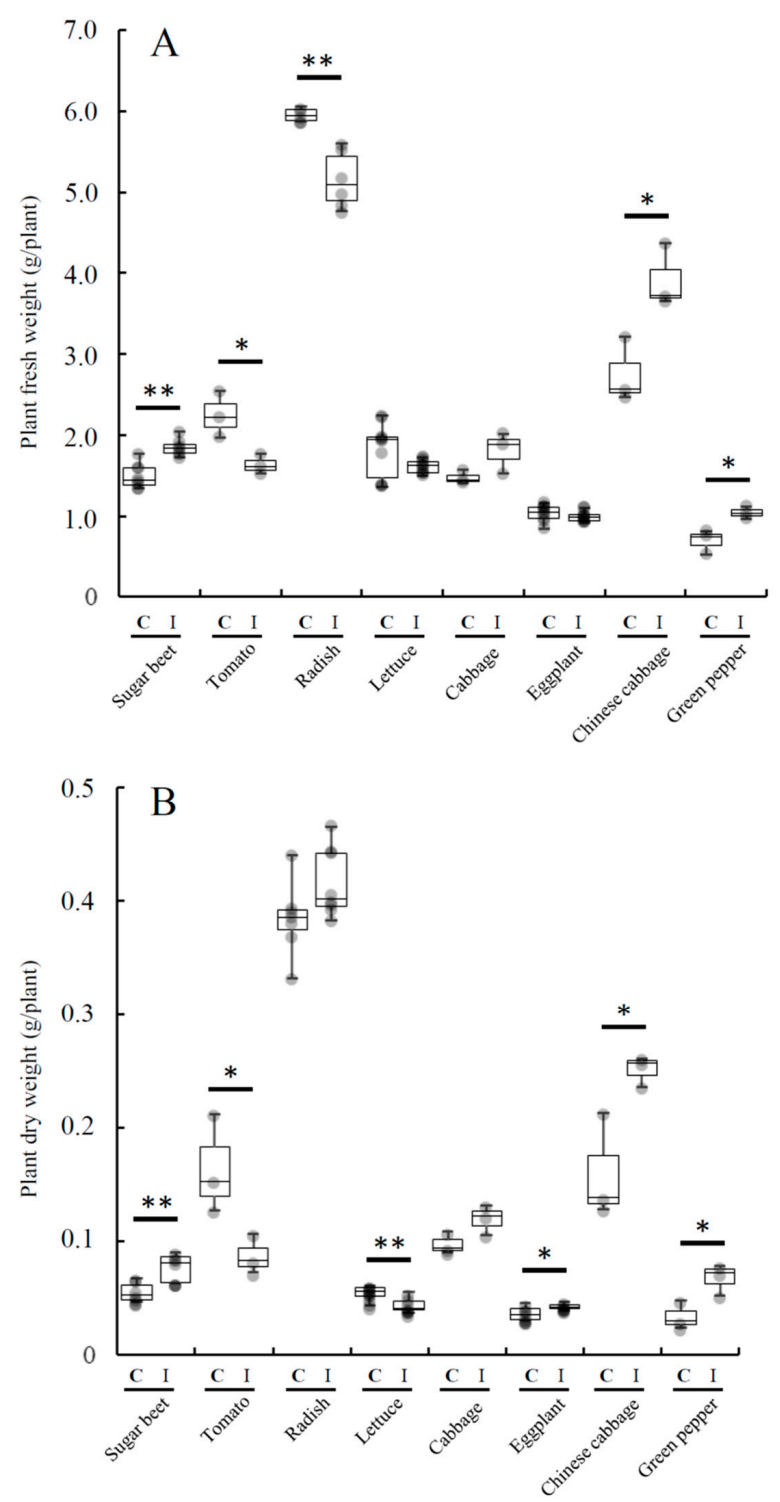

Figure 3. Effect of Variovorax sp. HRRK170 on the growth of vegetable seedlings. Plant fresh weights (A) and dry weights (B) are shown as means \pm standard deviation. Mean values were compared by t-test. Asterisks indicate significant $\left({ }^{*}, p<0.05 ;{ }^{* *}, p<0.01\right)$ differences between inoculated (I) and uninoculated control (C). Host plants used: tomato cv. Momotaro, radish cv. Taibyo sobutori, lettuce cv. Cisco, cabbage cv. Harunami, eggplant cv. Senryo 2 go, Chinese cabbage cv. Haregi 85, green pepper cv. Kyonami, and sugar beet cv. Rycka as a reference. 


\subsection{Plant Tissue Localization of HRRK 170}

Figure 4 shows localization of HRRK170 in plant tissue during its initial interaction with the seven vegetable seedlings and the sugar beet as a reference, 7 days post-inoculation. HRRK170 colonized all plants by 7 days post-inoculation, but was localized only in plant roots as shown in GUS-stained plant tissues. In addition, the localization profiles of HRRK170 in roots were divided into two types: entire and partial. The colonization throughout the roots was observed in Chinese cabbage (a), cabbage (b), lettuce (c), and radish (d), whereas partial but prominent colonization in the roots was in green pepper (spot-like colonization) (e), eggplant (uneven colonization) (f), tomato (uneven colonization) (g), and sugar beet (colonization including root hairs) (h) (Figure 4). Next, the transverse root sections were prepared and internal infection of HRRK170 into the plant tissue was assessed using GUS staining. Results indicated that HRRK170 localized to the epidermis, including root hairs, despite the localization profiles at 7 days post-inoculation (Figure 4).

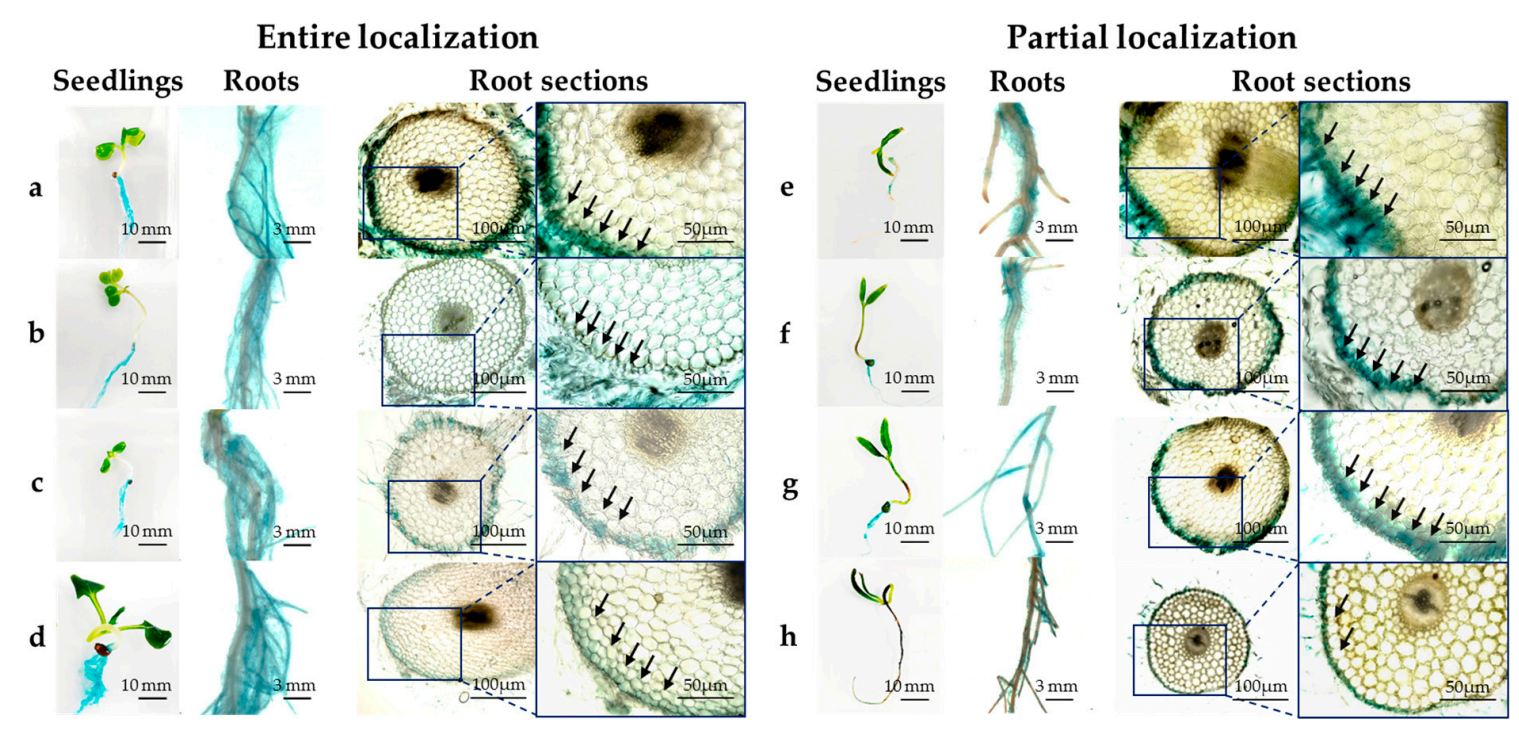

Figure 4. Tissue localization of Variovorax sp. HRRK170 in seven vegetable seedlings and sugar beet as a reference. The cells localized in the seedlings at 7 days post-inoculation were detected using GUS staining, and entire (left panels) and partial (right panels) localization was observed using a stereomicroscope. (a) Chinese cabbage (cv. Haregi 85), (b) cabbage (cv. Harunami), (c) lettuce (cv. Cisco), (d) radish (cv. Taibyo sobutori), (e) green pepper (cv. Kyonami), (f) eggplant (cv. Senryo 2 go), (g) tomato (cv. Momotaro), and (h) sugar beet (cv. Rycka) as a reference. Boxes show the enlarged regions in insets, and arrows indicate the localization of HRRK 170 cells. Photos of seedlings, roots, and root sections were obtained using a digital camera, stereomicroscope, and inverted microscope, respectively.

\subsection{Evaluation of HRRK 170 Cell Density Localized in the Plant Roots}

Since HRRK 170 promotes or represses plant growth, as shown in Figure 3, we tested the possibility that the cell density localized in the plant roots may explain this contradictory effect. Figure 5A shows the color development of GUS-staining solution using GUS-marked HRRK170 localized in the roots. This finding prompted us to estimate the cell density using the staining intensity because this method is faster and more convenient than the agar plate dilution method, which is generally used to count cell number.

To subject the staining intensity to colorimetry, the most appropriate wavelength in absorption spectra was first obtained from the color-developed solution caused by GUS-stained HRRK170 cells, i.e., absorbance at $615 \mathrm{~nm}$ was used as an index of staining intensity (Figure 5B). Then, the correlation between the cell density of HRRK170 (cell number per mL) and $\mathrm{OD}_{615}$ was assessed (Figure 6). Interestingly, the result indicated that $\mathrm{OD}_{615}$ was linearly correlated with the cell density obtained from plate dilution method, although absorbance data below or above 0.128 were fitted to different 
correlation coefficients in order to achieve better linearity (Figure 6). The cell densities were then estimated using $\mathrm{OD}_{615}$ with this correlation curve.

A

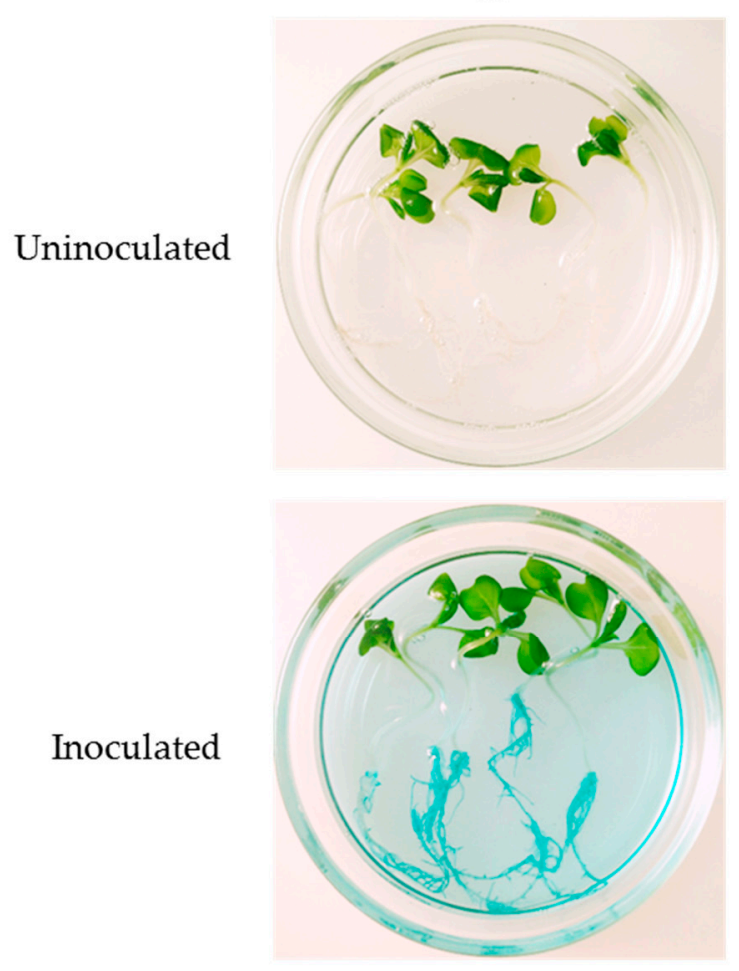

B
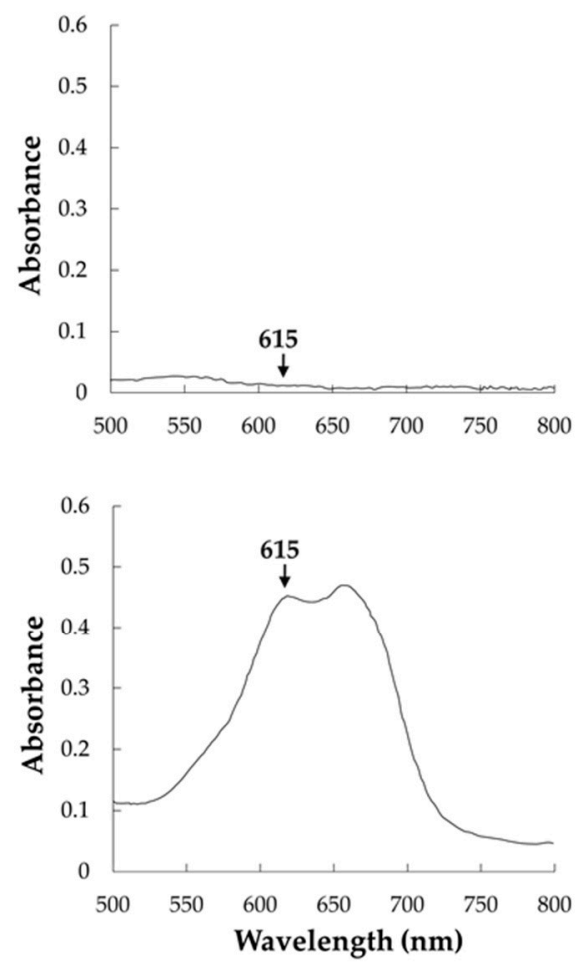

Figure 5. Color development in the reaction solution of GUS-stained Variovorax sp. HRRK 170 localized in the roots (Chinese cabbage, cv. Haregi 85) (A) and an absorption wavelength of the color-developed reaction solution (B). The absorbance of indigo-blue chromophore produced by the enzymatic hydrolysis of $\beta$-glucuronidase $\left(\mathrm{OD}_{615}\right)$ is shown by the arrows.

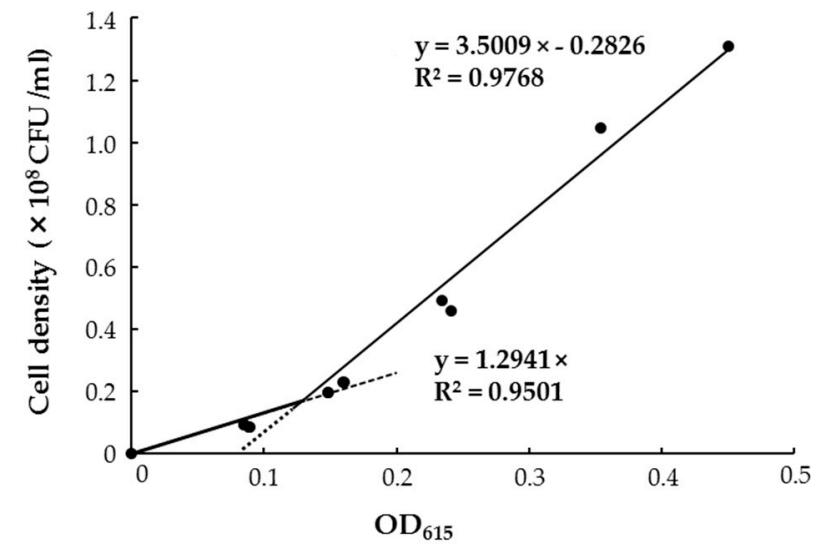

Figure 6. Correlation between Variovorax sp. HRRK 170 cell density and absorbance value $\left(\mathrm{OD}_{615}\right)$ of the reaction solution colored using GUS staining.

Figure 7A shows the relationship between cell density of HRRK170 (cell number per $\mathrm{g}$ of plant) and the plant growth ratio (percent of the inoculated plant weights against uninoculated control, which was calculated from the plant weights obtained in Figure 3) for seven vegetables with sugar beet as a reference. Results indicated that the plant growth ratio (\%) was closely related to the cell density and had its optimum values for the plant growth promotion, i.e., green pepper and Chinese cabbage exhibited higher values of both growth ratio and cell density than radish and lettuce, and their growth 
ratios were significantly higher than those of the other five vegetables (Figures 3 and 7A). Interestingly, the cell densities of cabbage, eggplant, and tomato were higher, while their growth ratios were lower than those of green pepper and Chinese cabbage. Notably, the growth ratio of tomato was considerably reduced, although it was infected with the highest number of cells.
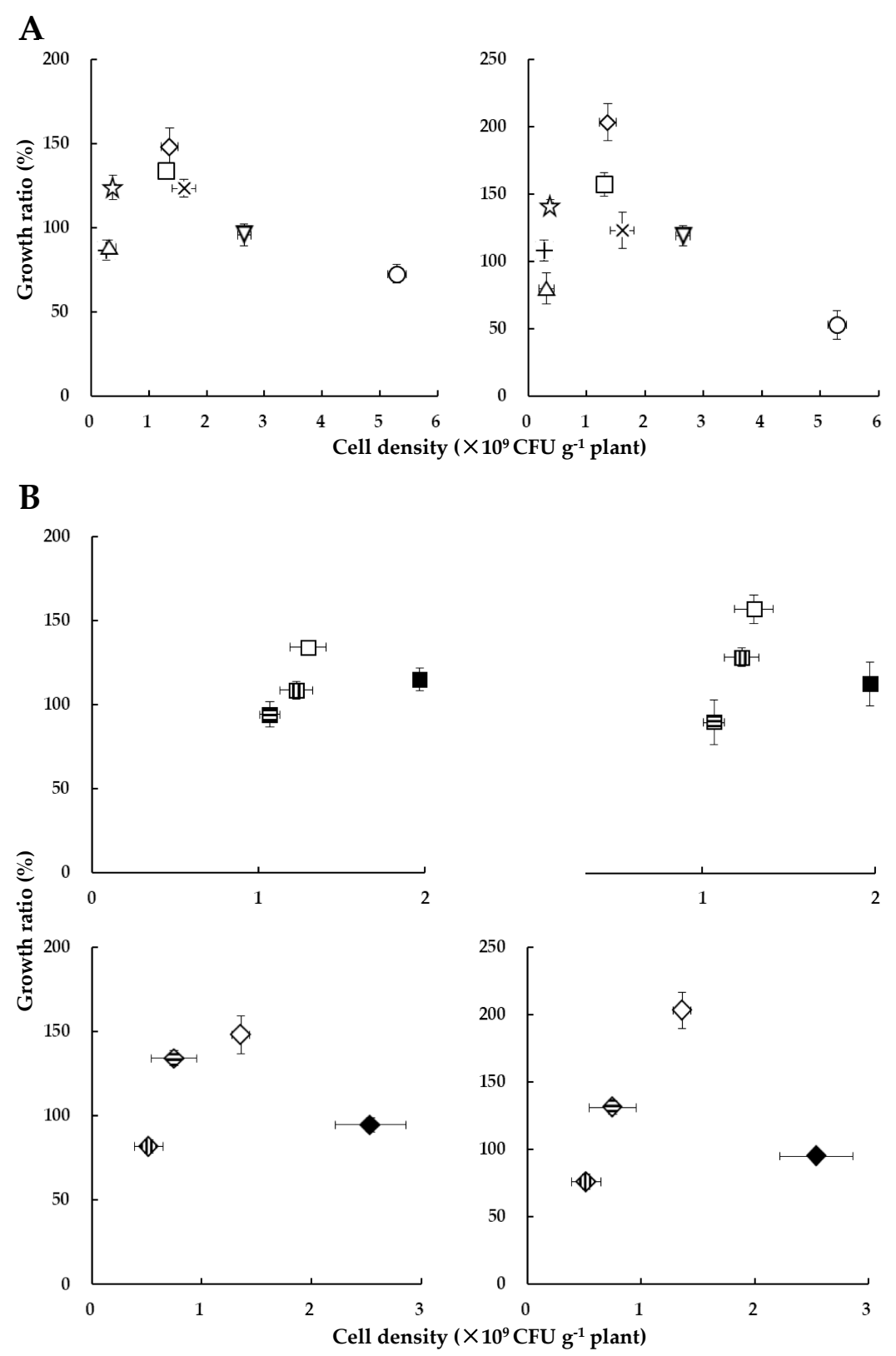

Figure 7. Relationship between Variovorax sp. HRRK 170 cell density and growth ratio (\%) of seedlings for seven vegetables, with sugar beet as a reference (A) and for the four cultivars of both Chinese cabbage and green pepper (B). Vertical axes show the ratio (\%) of the plant weight inoculated with HRRK 170 to that without it (growth ratio for fresh and dry weights is shown on the left and right, respectively). Cell density was calculated as the cell number per $g$ of plant using the correlation curve described in Figure 6. Vertical and horizontal bars show means \pm standard deviation. Symbols used (A): $\mathbf{O}$, tomato cv. Momotaro; +, radish cv. Taibyo sobutori; $\Delta$, lettuce cv. Cisco; $\mathbf{X}$, cabbage cv. Harunami; $\nabla$, eggplant cv. Senryo 2 go; $\square$, Chinese cabbage cv. Haregi 85; $\diamond$, green pepper cv. Kyonami; sugar beet cv. Rycka as a reference. (B): Chinese cabbage: $\square$, cv. Haregi 85; $\mathbf{E}$, cv. Kigokoro 65; 乔, cv. Kigokoro 85; $\mathbf{\square}$, cv. Okiniiri. Green pepper: $\diamond$, cv. Kyonami; $\vartheta$, cv. Kyomidori; $₫$, cv. Ace; $\diamond$, cv. Pitaro. 
Next, we sought to determine whether the relationship between the plant growth ratio and cell density would also be present in several cultivars of the same host plant. Therefore, we used four cultivars of Chinese cabbage and four of green pepper. Interestingly, a similar relationship was found in these cultivars, i.e., the plant growth ratio reflected a cell density-dependent manner with its optimum values (Figure 7B). Particularly, for green pepper, the growth ratio was increased with an increase in the cell density for the three cultivars (Ace, Kyomidori, and Kyonami, in this order), but decreased for the cultivar Pitaro, for which the cell density was the highest among the four cultivars (Figure 7B). These results indicated that HRRK170 promoted plant growth within a certain range of cell densities, i.e., at an optimum cell density for its full function in the early interaction with host plants.

\section{Discussion}

In this study, we screened six potential plant growth-promoting bacterial strains, which were previously isolated from sugar beet, and selected Variovorax sp. HRRK170 for having the highest ability to produce plant growth substances and enzymes such as siderophores and ACC deaminase, respectively (Table 1). HRRK170 also showed higher tolerance against lower temperature stress $\left(10^{\circ} \mathrm{C}\right)$ (Figure 1). In addition, biofilm production was evaluated at $20^{\circ} \mathrm{C}, 48 \mathrm{~h}$, because our preliminary experiment showed that a higher cell number was suited to the production of biofilms for the strains (Figure 1). The results showed that this strain also had a higher ability to produce biofilms (Table 1 and Figure 2). The type species, V. paradoxus, is known to have straight to slightly curved rods, and the colonies on nutrient agar are normally convex, glistening, shiny, and yellow or greenish yellow in color. Additionally, growth factors are not required because of the availability of a wide variety of organic compounds [28]. Genomic analyses by Han et al. revealed that V. paradoxus S110 was metabolically diverse and highly adaptable to various environmental conditions, and thus may support plant growth and degrade toxic compounds. This species may also promote plant growth by recruiting other bacteria that convert various substrates into cell biomass [29]. Belimov et al. reported that nitrogen accumulated in soils planted with seeds that were inoculated with $V$. paradoxus 5C-2 [9]. These results suggest that HRRK170 could be one of the most promising plant growth-promoting bioinoculants.

Notably, HRRK170 colonized the roots of all seven vegetable seedlings, as well as the sugar beet, seven days after inoculation and significantly promoted the growth of two vegetable seedlings (Chinese cabbage and green pepper) as well as the sugar beet, and also showed an upward tendency for two vegetable seedlings (cabbage and eggplant) (Figures 3 and 4). However, HRRK170 failed to function as a plant growth promoter for the other three vegetables (tomato, radish, and lettuce) (Figure 3). The colonization profiles of HRRK170 showed two different types (entire and partial) but did not seem to be correlated with the inoculation effects of HRRK170 (Figures 3 and 4). To elucidate the contradictory behavior of HRRK170, the number of HRRK170 cells infecting each plant was estimated in order to evaluate the relationship with plant growth promotion. Typically, cell numbers of the infecting strain are calculated via the plate dilution method after crushing plant tissues. However, since GUS-stained HRRK170 cells were found to cause color development due to GUS-staining solution, the cell number was estimated by the absorbance value $\left(\mathrm{OD}_{615}\right)$ because this method provided more accurate information after only $3.5 \mathrm{~h}$ incubation without crushing the plant tissues. The substrate, 5-bromo-4-chloro-3-indolyl- $\beta$-D-glucuronic acid (X-Gluc), for $\beta$-glucuronidase produces an insoluble, intense, indigo-blue chromophore $\left(\mathrm{OD}_{615}\right)$ after enzymatic hydrolysis [30]. Interestingly, the color development of the reaction solution is based on the production of this indigo-blue chromophore caused by enzymatic hydrolysis of $\mathrm{X}$-Gluc, and its absorbance value $\left(\mathrm{OD}_{615}\right)$, which is less than approximately 0.45 , correlated with the cell number, indicating that it could be estimated using this absorbance value (Figure 6). However, it remains unclear why this correlation curve does not show a simple linearity, since it is considered that the gus $A$ gene encoding B-glucuronidase is constitutively expressed from the promoter [31]. It may also be possible that the gusA expression was affected by cell number in such a way as to be lowered under higher cell number. 
The cell density of HRRK170 localized in the plant roots (cell number per $g$ of plant) could be estimated using this correlation curve because most of the cells localized on the epidermis despite the localization profiles at 7 days post-inoculation (Figure 4). This study showed that Variovorax sp. HRRK 170 promoted plant growth within a certain range of cell densities, indicating that it has an optimum cell density for its full function. Excess cell density may lose symbiotic balance with the host plant, whereas low affinity with the host plant results in low density of infecting cells. The complexity of beneficial plant-microbe interactions associated with cell number of microbes is still being discovered. Several studies have investigated the effects of initial inoculant concentration on plant growth. Larcher et al. reported that the initial dose of bacterial inoculant regulated the length of rapeseed root and shoot, suggesting that the cell number affects plant growth promotion [32]. Suckstorff et al. also reported that Stenotrophomonas sp. showed plant growth-promoting behavior in a dose-dependent manner [33]. In addition, efficient plant tissue localization of inoculants sustains plant growth in such a way as to increase the competitiveness against other soil microorganisms or to prevent the infection of harmful pathogens [22]. However, our results indicate that infecting cell density is an important factor in determining whether or not the bacterial strain fully functions to promote plant growth, and optimum cell density must be considered for the application of plant growth-promoting bioinoculants to host plants. Besides, prompt counting of cell number based on GUS-staining methodology would simplify the evaluation of infecting cell density in plants and provide new insight into plant-microbe interactions. Further studies are needed to clarify how the infecting cell density affects plant growth promotion.

Author Contributions: O.N. and T.O. designed the experiments and wrote the manuscript; O.N., H.S., D.M.O.S., and C.D.S. performed the experiments; K.O. and S.I. isolated bacterial strains and revised the paper; O.N., H.S., and Y.O. drew the figures and table with statistical analyses.

Funding: This work was supported by the Ministry of Agriculture, Forestry, and Fisheries, Japan, through research projects entitled "Development of Technologies for Mitigation and Adaptation to Climate Change in Agriculture, Forestry, and Fisheries" and "Science and Technology Research Promotion for Agriculture, Forestry, Fisheries, and the Food Industry".

Conflicts of Interest: The authors declare no conflicts of interest.

\section{References}

1. Neumann, G. Root exudates and nutrient cycling. In Nutrient Cycling in Terrestrial Ecosystems; Marschner, P., Rengel, Z., Eds.; Soil Biology; Springer: Berlin/Heidelberg, Germany, 2007; pp. 123-157, ISBN 978-3-540-68027-7.

2. Shahzad, S.M.; Arshad, M.; Khalid, M.; Mehboob, I. Integrated use of plant growth promoting bacteria and p-enriched compost for improving growth, yield and nodulation of chickpea. Pak. J. Bot. 2008, 40, 1735-1741.

3. Olanrewaju, O.S.; Glick, B.R.; Babalola, O.O. Mechanisms of action of plant growth promoting bacteria. World J. Microbiol. Biotechnol. 2017, 33, 197. [CrossRef] [PubMed]

4. De Souza, R.; Ambrosini, A.; Passaglia, L.M.P. Plant growth-promoting bacteria as inoculants in agricultural soils. Genet. Mol. Biol. 2015, 38, 401-419. [CrossRef] [PubMed]

5. Vessey, J.K. Plant growth promoting rhizobacteria as biofertilizers. Plant Soil 2003, 255, 571-586. [CrossRef]

6. Tsurumaru, H.; Okubo, T.; Okazaki, K.; Hashimoto, M.; Kakizaki, K.; Hanzawa, E.; Takahashi, H.; Asanome, N.; Tanaka, F.; Sekiyama, Y.; et al. Metagenomic analysis of the bacterial community associated with the taproot of sugar beet. Microbes Environ. 2015, 30, 63-69. [CrossRef] [PubMed]

7. Glick, B.R. Modulation of plant ethylene levels by the bacterial enzyme ACC deaminase. FEMS Microbiol. Lett. 2005, 251, 1-7. [CrossRef] [PubMed]

8. Van Veen, J.A.; van Overbeek, L.S.; van Elsas, J.D. Fate and activity of microorganisms introduced into soil. Microbiol. Mol. Biol. Rev. 1997, 61, 121-135. [PubMed]

9. Belimov, A.A.; Dodd, I.C.; Hontzeas, N.; Theobald, J.C.; Safronova, V.I.; Davies, W.J. Rhizosphere bacteria containing 1-aminocyclopropane-1-carboxylate deaminase increase yield of plants grown in drying soil via both local and systemic hormone signalling. New Phytol. 2009, 181, 413-423. [CrossRef] [PubMed] 
10. Zaidi, A.; Khan, M.S.; Saif, S.; Rizvi, A.; Ahmed, B.; Shahid, M. Role of nitrogen-fixing plant growth-promoting rhizobacteria in sustainable production of vegetables: current perspective. In Microbial Strategies for Vegetable Production; Zaidi, A., Khan, M.S., Eds.; Springer International Publishing: Cham, Switzerland, 2017; pp. 49-79, ISBN 978-3-319-54401-4.

11. Tien, T.M.; Gaskins, M.H.; Hubbell, D.H. Plant growth substances produced by Azospirillum brasilense and their effect on the growth of pearl millet (Pennisetum americanum L.). Appl. Environ. Microbiol. 1979, 37, 1016-1024. [PubMed]

12. Toyota, K.; Watanabe, T. Recent trends in microbial inoculants in agriculture. Microbes Environ. 2013, 28, 403-404. [CrossRef] [PubMed]

13. Lugtenberg, B.; Kamilova, F. Plant growth promoting rhizobacteria. Annu. Rev. Microbiol. 2009, 63, 541-556. [CrossRef] [PubMed]

14. Danhorn, T.; Fuqua, C. Biofilm formation by plant-associated bacteria. Annu. Rev. Microbiol. 2007, 61, 401-422. [CrossRef] [PubMed]

15. Noirot-Gros, M.-F.; Shinde, S.; Larsen, P.E.; Zerbs, S.; Korajczyk, P.J.; Kemner, K.M.; Noirot, P.H. Dynamics of aspen roots colonization by Pseudomonads reveals strain-specific and mycorrhizal-specific patterns of biofilm formation. Front. Microbiol. 2018, 9, 853. [CrossRef] [PubMed]

16. Rejeb, I.B.; Pastor, V.; Mauch-Mani, B. Plant responses to simultaneous biotic and abiotic stress: Molecular mechanisms. Plants 2014, 3, 458-475. [CrossRef] [PubMed]

17. Shoji, S.; Takahashi, T. Environmental and agricultural significance of volcanic ash soils. Glob. Environ. Res. 2002, 6, 113-135.

18. Samac, D.A.; Tesfaye, M. Plant improvement for tolerance to aluminum in acid soils-A review. Plant Cell Tissue Org. 2003, 75, 189-207. [CrossRef]

19. Okazaki, K.; Iino, T.; Kuroda, Y.; Taguchi, K.; Takahashi, H.; Ohwada, T.; Tsurumaru, H.; Okubo, T.; Minamisawa, K.; Ikeda, S. An assessment of the diversity of culturable bacteria from main root of sugar beet. Microbes Environ. 2014, 29, 220-223. [CrossRef] [PubMed]

20. Schwyn, B.; Neilands, J.B. Universal chemical assay for the detection and determination of siderophores. Anal. Biochem. 1987, 160, 47-56. [CrossRef]

21. Yuttavanichakul, W.; Lawongsa, P.; Wongkaew, S.; Teaumroong, N.; Boonkerd, N.; Nomura, N.; Tittabutr, P. Improvement of peanut rhizobial inoculant by incorporation of plant growth promoting rhizobacteria (PGPR) as biocontrol against the seed borne fungus, Aspergillus niger. Biol. Control 2012, 63, 87-97. [CrossRef]

22. Santiago, C.D.; Yagi, S.; Ijima, M.; Nashimoto, T.; Sawada, M.; Ikeda, S.; Asano, K.; Orikasa, Y.; Ohwada, T. Bacterial compatibility in combined inoculations enhances the growth of potato seedlings. Microbes Environ. 2017, 32, 14-23. [CrossRef] [PubMed]

23. Penrose, D.M.; Glick, B.R. Methods for isolating and characterizing ACC deaminase-containing plant growth-promoting rhizobacteria. Physiol. Plant. 2003, 118, 10-15. [CrossRef] [PubMed]

24. O'Brien, M.; Colwell, R.R. A rapid test for chitinase activity that uses 4-methylumbelliferyl-N-acetyl-betaD-glucosaminide. Appl. Environ. Microbiol. 1987, 53, 1718-1720. [PubMed]

25. Crabbe, J.R.; Campbell, J.R.; Thompson, L.; Walz, S.L.; Schultz, W.W. Biodegradation of a colloidal ester-based polyurethane by soil fungi. Int. Biodeterior. Biodegrad. 1994, 33, 103-113. [CrossRef]

26. Bhattacharya, A.; Chanda, S.; Barik, S. Lipase and protease producing microbes from the environment of sugar beet field. Ind. J. Agric. Biochem. 2009, 22, 26-30.

27. Simon, R. High frequency mobilization of gram-negative bacterial replicons by the in vitro constructed Tn5-Mob transposon. Mol. Gen. Genet. 1984, 196, 413-420. [CrossRef] [PubMed]

28. Willems, A.; Mergaert, J.; Swings, J. Variovorax. In Bergey's Manual of Systematics of Archaea and Bacteria; Whitman, W.B., DeVos, P., Dedysh, S., Hedlund, B., Kämpfer, P., Rainey, F., Trujillo, M.E., Bowman, J.P., Brown, D.R., Glöckner, F.O., et al., Eds.; American Cancer Society: Hoboken, NJ, USA, 2015; pp. 1-9, ISBN 978-1-118-96060-8.

29. Han, J.-I.; Choi, H.-K.; Lee, S.-W.; Orwin, P.M.; Kim, J.; Laroe, S.L.; Kim, T.-G.; O’Neil, J.; Leadbetter, J.R.; Lee, S.Y.; et al. Complete genome sequence of the metabolically versatile plant growth-promoting endophyte Variovorax paradoxus S110. J. Bacteriol. 2011, 193, 1183-1190. [CrossRef] [PubMed]

30. 5-Bromo-4-chloro-3-indolyl- $\beta$-D-glucuronic Acid, Cyclohexylammonium Salt-CAS 18656-96-7-Calbiochem 203783. Available online: https:/ / www.sigmaaldrich.com/catalog/product/mm/203783 (accessed on 28 January 2019). 
31. Wilson, K.J.; Sessitsch, A.; Corbo, J.C.; Giller, K.E.; Akkermans, A.D.; Jefferson, R.A. beta-Glucuronidase (GUS) transposons for ecological and genetic studies of rhizobia and other gram-negative bacteria. Microbiology 1995, 141, 1691-1705. [CrossRef] [PubMed]

32. Larcher, M.; Rapior, S.; Cleyet-Marel, J.-C. Bacteria from the rhizosphere and roots of Brassica napus influence its root growth promotion by Phyllobacterium brassicacearum. Acta Bot. Gallica 2008, 155, 355-366. [CrossRef]

33. Suckstorff, I.; Berg, G. Evidence for dose-dependent effects on plant growth by Stenotrophomonas strains from different origins. J. Appl. Microbiol. 2003, 95, 656-663. [CrossRef] [PubMed]

(C) 2019 by the authors. Licensee MDPI, Basel, Switzerland. This article is an open access article distributed under the terms and conditions of the Creative Commons Attribution (CC BY) license (http://creativecommons.org/licenses/by/4.0/). 